\title{
Anti-Saccharomyces cerevisiaeAntibodies in Patients with Inflammatory Bowel Disease and Their First-Degree Relatives: Potential Clinical Value
}

\author{
J. Glas ${ }^{a} \quad$ H.-P. Török ${ }^{a} \quad$ F. Vilsmaiera K.-H. Herbingerb M. Hoelscherb \\ C. Folwacznyc \\ a Medizinische Klinik; b Abteilung Infektions- und Tropenmedizin der Medizinischen Klinik und \\ cMedizinische Poliklinik, Standort Innenstadt der Ludwig-Maximilians-Universität München, Deutschland
}

\section{Key Words}

Anti-Saccharomyces cerevisiae antibodies (ASCA) . Immunoglobulin A (IgA) • Immunoglobulin G (IgG) • Inflammatory bowel disease - Crohn's disease .

Ulcerative colitis · Infectious enterocolitis

\begin{abstract}
Anti-Saccharomyces cerevisiae antibodies (ASCA) have been described as specific markers in Crohn's disease and their healthy first-degree relatives. 171 patients with Crohn's disease, their 105 first-degree relatives, 145 patients with ulcerative colitis and 101 first-degree relatives of patients with ulcerative colitis, 50 patients with infectious enterocolitis and 100 healthy controls were tested for ASCA employing the ELISA technique. When compared with the healthy controls $(p<0.0001)$ and patients with infectious enterocolitis $(p<0.0001)$ the prevalence of ASCA was significantly increased in patients with Crohn's disease and their first-degree relatives $(p<0.01)$. Further significant differences concerning the frequency of ASCA within the different groups of our study population were not observed. In particular, ASCA were not found in increased prevalence in infectious enterocolitis.
\end{abstract}

These observations are compatible with a role of ASCA as a marker of genetic predisposition to Crohn's disease.

Copyright $\odot 2002$ S. Karger AG, Basel

\section{Introduction}

In patients with inflammatory bowel diseases, various autoantibodies, such as perinuclear antineutrophilic cytoplasmatic antibodies (pANCA), antibodies against exocrine pancreas (PAK), colonic epithelial cells, intestinal goblet cells and endothelial cells have been described in recent years [1-15]. Apart from the differentiation between Crohn's disease and ulcerative colitis in rare cases of undetermined colitis, in particular the pathophysiologic importance of these serological markers remains to be elucidated. In view of the current literature it is unlikely that autoantibodies are involved in the pathophysiology of Crohn's disease or ulcerative colitis, e.g. by mediating cytotoxicity against colonic epithelial cells. Rather, they are the result of a cross-reactivity between the respective target antigen (or tissue) used for their detection via indirect immunofluorescence or ELISA and yet undeter-

\section{KARGER \\ Fax +41613061234 \\ E-Mail karger@karger.ch \\ www.karger.com \\ (C) 2002 S. Karger AG, Basel \\ 0012-2823/02/0663-0173\$18.50/0 \\ Accessible online at: www. karger.com/dig}

Priv.-Doz. Dr. med. Christian Folwaczny, Medizinische Poliklinik und Chirurgische Klinik und Poliklinik, Klinikum der Ludwig-Maximilians-Universität München Standort Innenstadt, Pettenkoferstrasse 8a, D-80336 München (Germany) Tel. +49 8951602625 , Fax +498951604187

E-Mail Christian.Folwaczny@medinn.med.uni-muenchen.de 
mined luminal antigens. Moreover, for some autoantibodies familial clustering has been described, which means that the respective autoantibody was not only present in patients with inflammatory bowel disease but although in their healthy first-degree relatives who display a 10- to 15-fold increased risk to develop either Crohn's disease or ulcerative colitis throughout their lifetime. These observations are compatible with a role of the respective autoantibody as a genetic marker of inflammatory bowel disease. The latter assumption is further supported if the prevalence of the respective autoantibody was not enhanced in patients with infectious enterocolitis. To the best of our knowledge, with the exception of endothelial cell autoantibodies previously described by our group [10], this was the case for all other autoantibodies with familial occurrence. These findings additionally argue against a role of the different autoantibodies as an environmental marker, which might become positive if individuals share the same environment, but rather it is compatible with a role as a genetic marker. In accordance with this hypothesis, pANCA were repeatedly described as useful tools to delineate genetically homogeneous subgroups of patients with inflammatory bowel disease [16, 17].

Recently, anti-Saccharomyces cerevisiae antibodies (ASCA), which are directed against oligomannosidic epitopes within the cell wall of yeast cells, have been described in $40-70 \%$ of patients with Crohn's disease [18-20]. Like other autoantibodies, ASCA have been described in $20-25 \%$ of unaffected first-degree relatives of patients with Crohn's disease [21-24]. Yeast cells are a part of the normal intestinal flora. Yeasts are also widely used for production of food as bread and beer and thus come into contact with the intestinal epithelium and the intestinal mucosal immune system. The present study was performed retrospectively to assess the frequency of ASCA in patients with Crohn's disease, ulcerative colitis and two separate cohorts of healthy first-degree relatives of patients with inflammatory bowel disease. In order to clarify whether these autoantibodies are genetic or environmental markers of disease susceptibility, their prevalence was additionally investigated in patients with different forms of infectious enterocolitis.

\section{Methods}

\section{Study Population}

171 sera from patients with Crohn's disease and 145 sera from patients with ulcerative colitis were tested for ASCA IgA and IgG. The diagnosis was based on conventional clinical, radiological, endoscopic and histological criteria and cases with undetermined colitis were excluded. Additionally, 105 sera from first-degree relatives of 45 patients within the group of patients with Crohn's disease and 101 sera from first-degree relatives of 35 patients within the group of patients with ulcerative colitis were investigated. Only healthy firstdegree relatives without clinical signs of inflammatory bowel disease were included. The latter were assessed by employing a standardized questionnaire. The first control group consisted of 100 sera from healthy, unrelated controls. The second control group comprised 50 patients with infectious enterocolitis (giardiasis, 15 cases; amebiasis, 13 cases; infection with campylobacter, 13 cases; infection with salmonella, 9 cases). The characteristics of the study population are depicted in table 1 . The study protocol had been approved by the local ethics committee.

\section{ASCA ELISA}

Sera of patients and controls were tested for both ASCA IgA and IgG using Medizym ${ }^{\circledR}$ ASCA IgA and Medizym ${ }^{\circledR}$ ASCA IgG ELISA kits from Medipan Diagnostica, Selchow, Germany. $100 \mu \mathrm{l}$ of serum and control samples diluted $1 / 51$ in the ready-for-use diluent was added to the 96-well microtiter plates coated with the specific antigen (mannan from S. cerevisiae). The plates were covered and incubated for $60 \mathrm{~min}$ at $37^{\circ} \mathrm{C}$. The unbound serum components were removed and the plates were washed 5 times with $300 \mu 1$ of washing buffer. $100 \mu \mathrm{l}$ of anti-human IgA or IgG antibodies conjugated with horseradish peroxidase were added, which reacted with the antibodies bound specifically to the antigen. After incubation for $30 \mathrm{~min}$ at $37^{\circ} \mathrm{C}$ the unbound conjugates were removed and the plates were

Table 1. Characteristics of the study population

\begin{tabular}{|c|c|c|c|c|c|c|}
\hline & \multirow[t]{2}{*}{$\begin{array}{l}\text { Crohn's } \\
\text { disease }\end{array}$} & \multirow[t]{2}{*}{$\begin{array}{l}\text { Ulcerative } \\
\text { colitis }\end{array}$} & \multicolumn{2}{|c|}{$\begin{array}{l}\text { First-degree relatives } \\
\text { of patients with }\end{array}$} & \multirow[t]{2}{*}{$\begin{array}{l}\text { Infectious } \\
\text { enterocolitis }\end{array}$} & \multirow[t]{2}{*}{$\begin{array}{l}\text { Healthy } \\
\text { controls }\end{array}$} \\
\hline & & & Crohn's disease & ulcerative colitis & & \\
\hline Number & 171 & 145 & 105 & 101 & 50 & 100 \\
\hline $\begin{array}{l}\text { Male/female ratio } \\
\text { Age, vears }\end{array}$ & $63 / 108$ & $71 / 74$ & $55 / 50$ & $51 / 50$ & $22 / 28$ & $57 / 43$ \\
\hline Mean \pm SD & $39.8 \pm 13.8$ & $42.4 \pm 12.8$ & $31 \pm 8$ & $36 \pm 9$ & $34 \pm 11$ & $39 \pm 12$ \\
\hline Range & $16-76$ & $17-76$ & $19-69$ & $17-61$ & $4-57$ & $20-61$ \\
\hline
\end{tabular}


washed 5 times with $300 \mu 1$ of washing buffer. Then $100 \mu$ of substrate $\left(3,3^{\prime}, 5,5^{\prime}\right.$-tetramethylbenzidine in citrate buffer with hydrogen peroxide) were added. The plates were incubated for $10 \mathrm{~min}$ at room temperature in the dark and the enzyme reaction was stopped by adding $100 \mu \mathrm{l}$ of stop solution $(0.25 \mathrm{M}$ sulfuric acid for IgA, $1 \mathrm{M}$ sulfuric acid for $\mathrm{IgG})$. The plates were read at $450 \mathrm{~nm}$ using a microplate reader (Tosoh Corp., Tokyo, Japan). Diluted human sera provided by the manufacturer served as internal controls. In the case of the $\mathrm{IgA}$ assay, four calibrators were used $(20,40,70,300 \mathrm{U} / \mathrm{ml})$, in the case of the IgG assay three control samples (ASCA IgG-positive control, ASCA IgG-negative control, ASCA IgG cut-off control). For qualitative evaluation the binding index $\left(\mathrm{BI}=\mathrm{OD}_{\text {sample }} /\right.$ $\mathrm{OD}_{\text {cut-off control }}$ ) was calculated. The cut-off control for the IgA assay was the $20 \mathrm{U} / \mathrm{ml}$ calibrator. The sample was considered positive at a $\mathrm{BI} \geq 1.0$. Additionally, the IgA assay was evaluated quantitatively by calculation of a standard curve from the four calibrators. The sample was considered positive for calculated at values $\geq 20 \mathrm{U} / \mathrm{ml}$. For every sample, two analyses on the same plate were carried out. Statistical analysis was performed using $\chi^{2}$ test and Fisher's exact test.

\section{Results}

When compared with the healthy controls $(\mathrm{p}<0.0001)$ and patients with infectious enterocolitis $(p<0.0001)$, the ASCA frequency was significantly increased in patients with Crohn's disease regardless of the IgA or IgG type of ASCA. In first-degree relatives of patients with Crohn's disease, only the $\operatorname{IgA}(\mathrm{p}<0.05)$ or the combination of the IgA and $\operatorname{IgG}$ type $(\mathrm{p}<0.01)$ of ASCA was found in increased frequency in comparison with the healthy controls. Separate and combined frequencies of ASCA IgA and $\mathrm{IgG}$ are given in table 2 and 3, respectively. The ASCA status was compared between first-degree relatives of ASCA-positive index patients and ASCA-positive relatives of ASCA-negative index patients with Crohn's disease. However, a significant difference between these

Table 2. Frequencies of ASCA IgA and IgG in patients with Crohn's disease and ulcerative colitis and their unaffected first-degree relatives compared with those frequencies observed in the healthy controls $\left({ }^{a}\right)$ and patients with infectious enterocolitis $\left({ }^{b}\right)$

\begin{tabular}{|c|c|c|c|c|}
\hline & $\operatorname{IgA}(\%)$ & $\mathrm{p}$ value & $\operatorname{IgG}(\%)$ & $\mathrm{p}$ value \\
\hline Patients with Crohn's disease $(\mathrm{n}=171)$ & $77(45.0 \%)$ & $\begin{array}{l}<0.0001^{\mathrm{a}} \\
<0.0001^{\mathrm{b}}\end{array}$ & $70(40.9 \%)$ & $\begin{array}{l}<0.0001^{\mathrm{a}} \\
<0.0001^{\mathrm{b}}\end{array}$ \\
\hline $\begin{array}{l}\text { First-degree relatives of patients with } \\
\text { Crohn's disease }(\mathrm{n}=105)\end{array}$ & $13(12.4 \%)$ & $\begin{array}{l}<0.05^{\mathrm{a}} \\
\text { n.s. }\end{array}$ & $5(4.8 \%)$ & $\begin{array}{l}\text { n.s. } \\
\text { n.s. }\end{array}$ \\
\hline Patients with ulcerative colitis $(n=145)$ & $9(6.2 \%)$ & $\begin{array}{l}\text { n.s. }{ }^{\mathrm{a}} \\
\text { n.s. }\end{array}$ & $5(3.4 \%)$ & $\begin{array}{l}\text { n.s. }{ }^{a} \\
\text { n.s. }\end{array}$ \\
\hline $\begin{array}{l}\text { First-degree relatives of patients with } \\
\text { ulcerative colitis }(\mathrm{n}=101)\end{array}$ & $3(3.0 \%)$ & $\begin{array}{l}\text { n.s. }{ }^{a} \\
\text { n.s. }\end{array}$ & $2(2.0 \%)$ & $\begin{array}{l}\text { n.s. }{ }^{\mathrm{a}} \\
\text { n.s. }\end{array}$ \\
\hline $\begin{array}{l}\text { Healthy controls }(n=100) \\
\text { Patients with infectious enterocolitis }(n=50)\end{array}$ & $\begin{array}{l}3(3.0 \%) \\
2(4.0 \%)\end{array}$ & & $\begin{array}{l}3(3.0 \%) \\
2(4.0 \%)\end{array}$ & \\
\hline
\end{tabular}

Table 3. Combined frequencies of ASCA IgA and IgG in patients with Crohn's disease and ulcerative colitis and their unaffected first-degree relatives compared with those frequencies observed in the healthy controls $\left({ }^{a}\right)$ and patients with infectious enterocolitis (b)

\begin{tabular}{|c|c|c|c|c|}
\hline & $\begin{array}{l}\operatorname{IgA} \text { and } \operatorname{IgG} \\
(\%)\end{array}$ & $\mathrm{p}$ value & $\begin{array}{l}\operatorname{IgA} \text { or } \operatorname{Ig} G \\
(\%)\end{array}$ & $\mathrm{p}$ value \\
\hline Patients with Crohn's disease $(\mathrm{n}=171)$ & $55(32.2 \%)$ & $\begin{array}{l}<0.0001^{\mathrm{a}} \\
<0.0001^{\mathrm{b}}\end{array}$ & $93(54.4 \%)$ & $\begin{array}{l}<0.0001^{\mathrm{b}} \\
<0.0001^{\mathrm{b}}\end{array}$ \\
\hline $\begin{array}{l}\text { First-degree relatives of patients with } \\
\text { Crohn's disease }(\mathrm{n}=105)\end{array}$ & $1(1.0 \%)$ & $\begin{array}{l}\text { n.s. }{ }^{\mathrm{a}} \\
\text { n.s. }\end{array}$ & $17(16.2 \%)$ & $\begin{array}{l}<0.01^{\mathrm{a}} \\
\text { n.s. }\end{array}$ \\
\hline Patients with ulcerative colitis $(n=145)$ & $0(0 \%)$ & $\begin{array}{l}\text { n.s. }{ }^{a} \\
\text { n.s. }\end{array}$ & $14(9.7 \%)$ & $\begin{array}{l}\text { n.s. }{ }^{\mathrm{a}} \\
\text { n.s. }\end{array}$ \\
\hline $\begin{array}{l}\text { First-degree relatives of patients with } \\
\text { ulcerative colitis }(\mathrm{n}=101)\end{array}$ & $0(0.0 \%)$ & $\begin{array}{l}\text { n.s. }{ }^{a} \\
\text { n.s. }\end{array}$ & $5(5.0 \%)$ & $\begin{array}{l}\text { n.s. }{ }^{\mathrm{a}} \\
\text { n.s. }\end{array}$ \\
\hline $\begin{array}{l}\text { Healthy controls }(n=100) \\
\text { Patients with infectious enterocolitis }(n=50)\end{array}$ & $\begin{array}{l}2(2.0 \%) \\
1(2.0 \%)\end{array}$ & & $\begin{array}{l}4(4.0 \%) \\
3(3.0 \%)\end{array}$ & \\
\hline
\end{tabular}

Anti-S. cerevisiae Antibodies in Patients 
Table 4. Comparison of ASCA status of the patients with Crohn's disease and their first-degree relatives

\begin{tabular}{lllr}
\hline & $\begin{array}{l}\text { First-degree } \\
\text { relatives } \\
\text { ASCA+ }\end{array}$ & $\begin{array}{l}\text { First-degree } \\
\text { relatives } \\
\text { ASCA- }\end{array}$ & $\Sigma$ \\
\hline Patients ASCA+ & 8 & 38 & 46 \\
Patients ASCA- & 9 & 50 & 59 \\
$\Sigma$ & 17 & 88 & 105 \\
\hline
\end{tabular}

The $p$ value, which was calculated for the ASCA+ relatives of ASCA+ patients against the ASCA+ relatives of ASCA- patients, was not significant.

groups was not observed. Moreover, correlation of ASCA titers between ASCA-positive relatives and the respective index patient was not observed. Further significant differences concerning the frequency of ASCA within the different groups of our study population were not observed (table 4).

\section{Discussion}

When compared with the two control groups, ASCA were found in significantly increased frequency in patients with Crohn's disease (54.4\%) and in their healthy first-degree relatives $(16.2 \%)$, whereas this was not the case in patients with ulcerative colitis and their healthy first-degree relatives [21-24]. These findings confirm the results of previous studies which described ASCA to be associated with Crohn's disease but not ulcerative colitis and which found a familial occurrence of ASCA. However, the frequencies demonstrated herein are somewhat lower than those described by other groups. In the study of Seibold et al. [22], the frequencies of ASCA were $68 \%$ in patients with Crohn's disease and $25 \%$ in their firstdegree relatives. In addition, other groups also found higher frequencies in patients with Crohn's disease and their first-degree relatives than described in our study [21, 23, 24]. Apart from ethnic differences, this might at least in part be explained by methodical reasons. In the study by Vermeire et al. [25], four different ASCA ELISA tests were compared. The range in sensitivity was $41-76 \%$ and the specificity ranged between 88.5 and $97.5 \%$. The assays used in the present study (Medipan) had the lowest sensitivity (41\%), but the highest specificity (97.5\%) when compared with other commercially available assays. The comparably high specificity might be of importance if
ASCA are employed in order to differentiate between ulcerative colitis and Crohn's disease which is confined to the colon. However, similar to other autoantibodies, such as pANCA [1] or antibodies against exocrine pancreas [9], the value of ASCA for the differential diagnosis between Crohn's disease and ulcerative colitis is limited by an insufficient sensitivity. The increased occurrence of ASCA in first-degree relatives of patients with Crohn's disease is compatible with a role of these antibodies as a marker of genetic disease susceptibility, because relatives of patients with inflammatory bowel disease are prone to develop Crohn's disease or ulcerative colitis. Based on our findings and literature data it appears unlikely that ASCA are the result of environmental antigenic stimuli. This conclusion is supported by the comparable low ASCA prevalence in the group of patients with infectious enterocolitis, which served as a second control group. Why ASCA similar to other autoantibodies display a familial occurrence remains to be elucidated. An increased permeability of the bowel wall has been described not only in patients with Crohn's disease and their healthy firstdegree relatives, but also in spouses of patients [26, 27]. Thus, a facilitated contact of antigens from yeast antigens occurring in nutriments might be an explanation for generation of ASCA. On the other hand, in the study by Vermeire et al. [24], intestinal permeability was significantly enhanced in patients with Crohn's disease, but the latter was not associated with the ASCA status of the respective patients. Thus, ASCA and increased permeability are most likely independent phenomena. Moreover, a familial aggregation of ASCA as observed in our study is not a unique feature of inflammatory bowel disease but can also be found in patients with diabetes mellitus and their relatives [28]. Thus, it remains unclear whether ASCA are pathogenic per se or only a specific phenomenon accompanying a subset of Crohn's disease. To answer this question it would be important to identify the antigen recognized by ASCA within the small bowel, which is currently unknown.

\section{Acknowledgement}

This paper contains parts of the doctoral thesis of F. Vilsmaier. $\overline{176} \quad \overline{\text { Digestion 2002;66:173-177 }}$
Glas/Török/Vilsmaier/Herbinger/ Hoelscher/Folwaczny 


\section{References}

1 Cambridge G, Rampton DS, Stevens TR, McCarthy DA, Kamm M, Leaker B: Antineutrophil antibodies in inflammatory bowel disease: Prevalence and diagnostic role. Gut 1992 . 33:668-674.

2 Colombel JF, Reumaux D, Duthilleul P, Noel LH, Gower-Rousseau C, Paris JC, Cortot A: Antineutrophil cytoplasmic autoantibodies in inflammatory bowel disease. Gastroenterol Clin Biol 1992; 16:656-660.

3 Das KM, Dubin R, Nagai T: Isolation and characterisation of colonic tissue-bound antibodies from patients with idiopathic ulcerative colitis. Proc Natl Acad Sci USA 1978;75:45284532

4 Duerr RH, Targan SR, Landers CJ, Sutherland LR, Shanahan F: Anti-neutrophil cytoplasmic antibodies in ulcerative colitis: Comparison with other colitides/diarrheal illnesses. Gastroenterology 1991;100:1590-1596.

5 Duerr RH, Targan SR, Landers CJ, LaRusso NF, Lindsay KL, Wiesner RH, Shanahan F: Neutrophil cytoplasmic antibodies: A link between primary sclerosing cholangitis and ulcerative colitis. Gastroenterology 1991;100:13851391.

6 Fiocchi C, Roche JK, Michener WM: High prevalence of antibodies to intestinal epithelial antigens in patients with inflammatory bowel disease and their relatives. Ann Intern Med 1989;110:786-794.

7 Folwaczny C, Noehl N, Endres SP, Heldwein W, Loeschke K, Fricke H: Antinuclear autoantibodies in patients with inflammatory bowe disease - High prevalence in first-degree relatives. Dig Dis Sci 1997;42:1593-1596.

8 Folwaczny C, Noehl N, Tschöpp K, Endres SP, Heldwein W, Loeschke K, Fricke H: Goblet cell autoantibodies in patients with inflammatory bowel disease and their first-degree relatives. Gastroenterology 1997;113:101-106.

9 Folwaczny C, Noehl N, Endres SP, Loeschke $\mathrm{K}$, Fricke $\mathrm{H}$ : Antineutrophil and pancreatic autoantibodies in first-degree relatives of patients with inflammatory bowel disease. Scand J Gastroenterol 1998;33:523-528.

10 Folwaczny C, Loeschke K, Schnettler D, Jäger G, Wiebecke B, Hoelscher M, Sauer T, König A, Endres SP, Fricke H: Endothelial cell autoantibodies are a marker of disease susceptibility in inflammatory bowel disease but apparently not linked to persistent measles virus infection. Clin Immunol 2000;95:197-202.
11 Hibi T, Ohara M, Toda K, Hara A, Ogata H, Iwao Y, Watanabe N, Watanabe M, Hamada Y, Kobayashi K: In vitro anticolon antibody production by mucosal or peripheral blood lymphocytes from patients with ulcerative colitis. Gut 1990;31:1371-1376.

12 Lee JC, Lennard-Jones JE, Cambridge G: Antineutrophil antibodies in familial inflammatory bowel disease. Gastroenterology 1995;108: 428-433.

13 Oudkerk Pool M, Ellerbroek PM, Ridwan BU, Goldschmeding R, von Blomberg BM, Pena AS, Dolman KM, Bril H, Dekker W, Nauta JJ: Serum antineutrophil cytoplasmic autoantibodies in inflammatory bowel disease are mainly associated with ulcerative colitis. A correlation study between perinuclear antineutrophil cytoplasmic autoantibodies and clinical parameters, medical and surgical treatment. Gut 1993;34:46-50.

14 Seibold F, Weber P, Jenss H, Wiedmann KH: Antibodies to a trypsin-sensitive pancreatic antigen in chronic inflammatory bowel disease: Specific markers for a subgroup of patients with Crohn's disease. Gut 1991;32:11921197.

15 Stöcker W, Otte M, Ulrich S, Normann D, Finkbeiner H, Stocker K, Jantschek G, Scriba PC: Autoimmunity: Pancreatic juice in Crohn's disease. Scand J Gastroenterol 1987; 22:41-52.

16 Yang H, Vora DK, Targan SR, Toyoda H, Beaudet AL, Rotter JI: Intercellular adhesion molecule 1 gene associations with immunologic subsets of inflammatory bowel disease. Gastroenterology 1995;109:440-448.

17 Yang H, Rottler JI, Toyoda H, Landers C, Tyran D, McElree CK, Targan SR: Ulcerative colitis: A genetically heterogeneous disorder defined by genetic (HLA class II) and subclinical (antineutrophil cytoplasmic antibodies) markers. J Clin Invest 1993;92:1080-1084.

18 Quinton JF, Sendid B, Reumaux B, Duthilleul P, Cartot A, Grandbastien B, Charrier G, Targan SR, Colombel JF, Poulain D: Anti-Saccharomyces cerevisiae mannan antibodies combined with antineutrophil cytoplasmic autoantibodies in inflammatory bowel disease: Prevalence and diagnostic role. Gut 1998;42:788791

19 Ruemmele FM, Targan SR, Levy G, Dubinsky M, Braun J, Seidman EG: Diagnostic accuracy of serological assays in pediatric inflammatory bowel disease. Gastroenterology 1998;115: 822-829.
20 Sendid B, Colombel F, Jaquinot PM, Faille C, Fruit J, Cortot A, Lucidarme D, Camus D, Poulain D: Specific antibody response to oligomannosidic epitopes in Crohn's disease. Clin Diagn Lab Immunol 1996;3:219-226.

21 Annese V, Andreoli A, Andriulli A, D'Inca R, Gionchetti P, Latiano A, Lombardi G, Piepoli A, Poulain D, Sendid B, Colombel JF: Familial expression of anti-Saccharomyces cerevisiae mannan antibodies in Crohn's disease and ulcerative colitis: A GISC study. Am J Gastroenterol 2001;96:2407-2412.

22 Seibold F, Stich O, Hufnagl R, Kamil S, Scheurlen M: Anti-Saccharomyces cerevisiae antibodies in inflammatory bowel disease: A family study. Scand J Gastroenterol 2001;36: 196-201.

23 Sendid B, Quinton JF, Charrier G, Goulet O, Cartot A, Grandbastien B, Poulain D, Colombel JF: Anti-Saccharomyces cerevisiae mannan antibodies in familial Crohn's disease. Am J Gastroenterol 1998;93:1306-1310.

24 Vermeire S, Peeters M, Vlietinck R, Joossens S Den Hond E, Bulteel V, Bossuyt X, Geypens B, Rutgeerts P: Anti-Saccharomyces cerevisiae antibodies, phenotypes of IBD, and intestinal permeability: A study in IBD families. Inflamm Bowel Dis 2001;7:8-15.

25 Vermeire S, Joosens S, Peeters M, Mansuur F, Marien G, Bossuyt X, Groenen P, Vlietinck R, Rutgeerts P: Comparative study of ASCA (antiSaccharomyces cerevisiae antibody) assays in inflammatory bowel disease. Gastroenterology 2001;120:827-833.

26 Peeters M, Geypens B, Claus D, Nevens H, Ghoos Y, Verbeke G, Baert F, Vermeire S, Vlietinck R, Rutgeerts P: Clustering of increased small intestinal permeability in families with Crohn's disease. Gastroenterology 1997;113:802-807.

27 Söderholm JD, Olaison G, Lindberg E, Hannestad U, Vindels A, Tysk C, Järnerot G, Sjödahl R: Different intestinal permeability patterns in relatives and spouses of patients with Crohn's disease: An inherited defect in mucosal defence? Gut 1999;44:96-100.

28 Poulain D, Sendid B, Fajardi I, Danze PM, Colombel JF: Mother to child transmission of anti-Saccharomyces cerevisiae mannan antibodies in non-IBD families. Gut 2000;47:870871. 